\title{
HEAVY METALS AND RADIONUCLIDES IN MUSCLES OF FISH SPECIES IN THE SOUTH ADRIATIC - MONTENEGRO
}

\author{
Ivanka Antović*, Danijela Šuković, Snežana Andjelić, Nikola Svrkota
}

Centre for Ecotoxicological Research, Podgorica, Montenegro

\begin{abstract}
This paper deals with the concentration of $\mathrm{Pb}, \mathrm{Cd}, \mathrm{Cu}, \mathrm{Fe}, \mathrm{Mn}, \mathrm{Ni}, \mathrm{Cr}$ and $\mathrm{Zn}$, and activity concentrations of ${ }^{137} \mathrm{Cs},{ }^{40} \mathrm{~K}$, as well as levels of ${ }^{226} \mathrm{Ra}$ and ${ }^{232} \mathrm{Th}$ through their daughters ${ }^{214} \mathrm{Bi}$ and ${ }^{228} \mathrm{Ac}$, in muscles of six fish species from the South Adriatic Sea adjacent to Montenegro. Specimens of three mullet species from the Liza genus - Liza aurata (golden grey mullet), Liza saliens (leaping mullet) and Liza ramada (thinlip grey mullet), were caught by a trawl net in the area of Tivat - Boka Kotorska Bay, as well as Merluccius merluccius (European hake), Dicentrarchus labrax (European seabass), Sparus aurata (gilt-head sea bream). Element concentrations were determined in a standard procedure using ICAP 6000 ICP-OES and atomic absorption spectrophotometer AA-680o, whilst radionuclide activity concentrations - in a standard HPGe ORTEC gamma spectrometry. The results showed a level of ${ }^{137 C s}$ somewhat lower than in the muscles of previously analyzed the other (mullet) species from the South Adriatic, in contrast to ${ }^{214} \mathrm{Bi}$ level which is mostly found to be slightly higher than its parent (226Ra) level in the other previously analyzed species. Committed effective dose from the annual intake of radionuclides due to an adult fish consumption is found to be highest for $M$. merluccius $(13.8 \mu \mathrm{Sv})$, showing all the radionuclides above minimum detectable activity. In muscle of L. aurata element concentrations were found to be ordered as: $\mathrm{Fe}>\mathrm{Zn}>\mathrm{Cr}>\mathrm{Mn}>\mathrm{Ni}>\mathrm{Cu}>\mathrm{Pb}>\mathrm{Cd}$. This species showed a concentration of each element higher than the other species (particularly $\mathrm{Pb}, \mathrm{Fe}, \mathrm{Mn}, \mathrm{Ni}$, and $\mathrm{Cr}$ ). The concentration of $\mathrm{Zn}$ only could be considered as more or less comparable in all the muscles. No one muscle showed a concentration of toxic trace elements $\mathrm{Pb}$ and $\mathrm{Cd}$ exceeding the limits from the EU regulations. A potential health risk associated with $\mathrm{Pb}$ and $\mathrm{Cd}$ intake due to consumption of analyzed fish species is estimated using the target hazard quotient found to be $\leq 0.055$.
\end{abstract}

Keywords: Fish, radionuclides, essential elements, toxic metals, health risks, South Adriatic

\section{INTRODUCTION}

It is well known that nowadays the contamination of the aquatic environment with heavy metals increases due to various artificial sources. An aquatic environment can also be contaminated by radioactivity originating from natural radioisotopes, the fallout from the atmosphere, and from radioactive effluents from various facilities (medical, industrial, nuclear).

The considerable ability for fish to accumulate heavy metals and radioisotopes even when their concentrations in water are small, pathways to fish tissues - important for understanding dynamics of the isotope in the aquatic environment, and known bioaccumulation, could be used in an aquatic environment monitoring. At the same time, metal bioaccumulation and distribution in fish organs were found to be highly inter-specific (e.g. [1, 2]).

Some of the heavy metals naturally occurring in the environment play an essential role in the metabolism and growth, and are not harmful to the organism except for high concentrations when they could produce toxic effects. On the other hand, some of them are toxic even in trace amounts, and the determination of metal concentrations in fish and its different organs is of considerable interest.

The essential trace elements, such as $\mathrm{Zn}$ and $\mathrm{Cu}$, are significant since "deficiency in human organism leads to several disorders, but an excessive $\mathrm{Zn}$ intake can cause acute adverse effects" and $\mathrm{Cu}$ "deficiency in adults can result in blood and nervous system disorders" as said in [1]. Furthermore, $\mathrm{Mn}$ is significant "for normal immune function, for regulation of blood sugar and cellular energy, reproduction, digestion, bone growth..." but also "may have toxic effects for human beings" [1].

International recommendations, standards and regulations from Food and Agriculture Organization of the United Nations (FAO), World Health Organization (WHO), European Union (EU) etc., usually deal with toxic trace elements (such as $\mathrm{Pb}, \mathrm{Cd}$ - that can generally be toxic to animals, plants, and humans).

So, FAO and WHO 1972 [3] in the evaluation of some food contaminants and additives, gave provisional tolerable weekly intake (for adults) of 3 and 0.4-0.5 mg per person, for $\mathrm{Pb}$ and $\mathrm{Cd}$, respectively, i.e. 0.05 and $0.0067-0.0083 \mathrm{mg} / \mathrm{kg}$ of body weight, respectively. In the compilation of legal limits for

*Ivanka_Antovic@yahoo.com 
hazardous substances in fish and fishery products, FAO 1983 [4], permissible limits in many countries for $\mathrm{Zn}$ and $\mathrm{Cu}$ are given together with the limits for toxic trace elements $(\mathrm{Pb}, \mathrm{Cd})$. Given limits for $\mathrm{Cu}$ in different countries were 10 (mostly), 20, 30 and $100 \mathrm{mg} / \mathrm{kg}$; for $\mathrm{Zn}-40,50,100$ and $150 \mathrm{mg} / \mathrm{kg}$. Permissible limits for $\mathrm{Pb}$ in different countries ranged from 0.05 to 10 $\mathrm{mg} / \mathrm{kg}$, for $\mathrm{Cd}$ - from 0.05 to $5.5 \mathrm{mg} / \mathrm{kg}$. One limit for $\mathrm{Cr}$ was also given (1 mg/kg (Hong Kong) [4]). In addition, the WHO 1989 technical report 776 [5] gave provisional tolerable weekly intake of $\mathrm{Cd}$ in an amount $0.007 \mathrm{mg} / \mathrm{kg}$ of body weight.

The European Commission regulation 78 [6], for example for grey mullet, set the maximum level of $\mathrm{Cd}$ "in the muscle meat of fish" of $0.1 \mathrm{mg} / \mathrm{kg}$ (wet weight), and $\mathrm{Pb}-0.4 \mathrm{mg} / \mathrm{kg}$. The national Montenegro regulations previously contained the same limits for $\mathrm{Cd}$ and $\mathrm{Pb}$ in fresh fish [7]. However, new regulations set $0.3 \mathrm{mg} / \mathrm{kg}$ as the maximum level of $\mathrm{Pb}$ in fish muscles (wet weight), and $0.05 \mathrm{mg} / \mathrm{kg}$ of $\mathrm{Cd}$, except for some fish species including grey mullet $(0.1 \mathrm{mg} / \mathrm{kg})$, but also Auxis species $(0.2 \mathrm{mg} / \mathrm{kg})$, Engraulis species and Xiphias gladius $(0.3 \mathrm{mg} / \mathrm{kg})$ [8].

Heavy metal concentrations and radioactivity in Montenegro beach sands were previously analyzed [9], and this study deals with the concentration of $\mathrm{Pb}, \mathrm{Cd}$, $\mathrm{Cu}, \mathrm{Fe}, \mathrm{Mn}, \mathrm{Ni}, \mathrm{Cr}$, and $\mathrm{Zn}$, together with activity concentrations of ${ }^{137} \mathrm{Cs}$ and ${ }^{40} \mathrm{~K}$ in eatable portions (muscles) of six commercially important fish species. It also deals with the levels of ${ }^{226} \mathrm{Ra}$ and ${ }^{232} \mathrm{Th}$ (through their daughters ${ }^{214} \mathrm{Bi}$ and ${ }^{228} \mathrm{Ac}$, respectively) in the same samples.

Considered fish species are European hake (Merluccius merluccius Linnaeus, 1758), European seabass (Dicentrarchus labrax Linnaeus, 1758), gilthead sea bream (Sparus aurata Linnaeus, 1758), and three mullet (Liza) species - golden grey mullet (Liza aurata Risso, 1810), leaping mullet (Liza saliens Risso, 1810) and thinlip grey mullet (Liza ramada Risso, 1826). It should be noted that the names of these Liza species are still under taxonomic discussion. For example, the World Register of Marine Species presently gives 'accepted names' Chelon auratus, Chelon saliens and Chelon ramada, respectively. They were collected from the South Adriatic Sea and measured in the Centre for Ecotoxicological Research in Podgorica, mostly in the frame of the research project supported by the Ministry of Science of Montenegro (01-571). One muscle of each species is selected for the analysis in the present study.

Among all (6) the Euro-Mediterranean mullet species occurring in the South Adriatic Sea (L. aurata, L. ramada and L. saliens, Mugil cephalus Linnaeus, 1758, Chelon labrosus Risso, 1826, Oedalechilus labeo Cuvier, 1829), three are from the Liza genus. As Thomson found [10], general distributions of these Liza species are: L. aurata - Black Sea, Mediterranean, Eastern Atlantic from Scotland to Cape Verde Islands (introduced into the Caspian Sea, as well), L. ramada Black Sea, Mediterranean, eastern Atlantic northern from Cape Verde Islands to North Sea and Baltic, $L$. saliens - Black Sea, Mediterranean, and introduced into the Caspian Sea.

Furthermore, M. merluccius is distributed along the Atlantic Coast (Europe and western North Africa), the Mediterranean and the Black Sea, as well as $D$. labrax (the North Atlantic, the Mediterranean and the Black Sea...), while S. aurata (Mediterranean, Atlantic - to Cape Verde and around the Canaries) is rare in the Black Sea [11].

Some of the abovementioned mullets were previously investigated radioecologically (e.g. [12, 13]). A study on activity concentration of the cosmogenic radionuclide $7 \mathrm{Be}$ in fish species from the South Adriatic Sea has also been performed recently [14].

\section{MATERIALS AND METHODS}

In order to complete the ecological and environmental picture, the present study has been conducted to analyze the muscles of the mentioned fish species and seawater for metal and radioactive isotopes. It is aimed to provide baselines for both further research and future comparison, and evaluation of potential risk for the fish themselves and their human consumers. The specimens were caught by a trawl net in the area of Tivat - Boka Kotorska Bay, Coast of Montenegro, in 2013-14 (mullets, including seawater from the same area), and in 2018 (the other species).

Total lengths and wet weights of whole individuals whose muscles are analyzed in this study were: European hake $-25.5 \mathrm{~cm}$ and $108 \mathrm{~g}$, gilt-head sea bream -24.2 and $200 \mathrm{~g}$, European seabass $-32.2 \mathrm{~cm}$ and $338 \mathrm{~g}-$ adult and 24.7 and $158 \mathrm{~g}$ - juvenile, golden grey mullet $-29.3 \mathrm{~cm}$ and $224 \mathrm{~g}$, leaping mullet -32.4 $\mathrm{cm}$ and $247 \mathrm{~g}$, and thinlip grey mullet $-37.4 \mathrm{~cm}$ and $338 \mathrm{~g}$.

Sample preparation and measurements were performed in an accredited laboratory of the Centre for Ecotoxicological Research in Podgorica. Standard preparation and measuring procedures were applied for the determination of the element concentrations, i.e., the AOAC Official Methods of Analysis (972.23, 986.15 and 999.11) and instruments - iCAP 6000 ICPOES (Thermo Scientific, UK) and Atomic Absorption Spectrophotometer AA-680o (Shimadzu, Japan). Validation of the method was carried out in accordance with the MEST ISO 17025 Standard, with the reference material Tuna Fish Flash Homogenate IAEA-436. All the elements were measured using the iCAP 6000, while the additional measurements of $\mathrm{Cu}, \mathrm{Fe}, \mathrm{Mn}, \mathrm{Cr}$, $\mathrm{Zn}$, Ni were performed using AA-680o (flame), and $\mathrm{Pb}$, $\mathrm{Cd}$ - using AA-680o (graphite).

A potential health risk associated with toxic trace elements intake due to consumption of analyzed fish species is estimated using the target hazard quotients (THQ) [15]

$\mathrm{THQ}=\left[\left(\mathrm{EF}^{\mathrm{T}} \mathrm{T}_{\mathrm{a}} \cdot \mathrm{FIR} \cdot \mathrm{C}_{\mathrm{m}}\right) /(\mathrm{ROD} \cdot \mathrm{ABW} \cdot \mathrm{ET})\right] \cdot 10^{-3}$,

where:

$\mathrm{EF}$ is exposure frequency of 365 days per year,

$\mathrm{T}_{\mathrm{a}}$ is an average lifetime taken to be 70 years,

FIR is the fish meat ingestion rate in an individual amount of $36 \mathrm{~g}$ per day (around $13 \mathrm{~kg}$ per year),

$\mathrm{C}_{\mathrm{m}}$ is the metal concentration (in $\mathrm{mg} / \mathrm{kg}$ wet weight),

ROD is the reference oral dose of $1 \cdot 10^{-3}$ for $\mathrm{Cd}$ and $4 \cdot 10^{-3}$ for $\mathrm{Pb}$ (in mg per $\mathrm{kg}$ and day),

ABW is the average adult consumer body weight taken as $67 \mathrm{~kg}$, 
ET is the exposure time (EF. $\left.\mathrm{T}_{\mathrm{a}}\right)$.

Since the samples were also analyzed for radioactivity, seawater (20L) was evaporated (to $1 \mathrm{~L}$ ) and sealed in $1 \mathrm{~L}$ Marinelli beaker, and fish samples were also prepared in the standard procedure, i.e., homogenized (freshly ground and mixed). The measurements were performed using the $50 \mathrm{~mL}$ cylindrical beakers at the coaxial HPGe spectrometers ORTEC GEM-40190 and ORTEC GEM-30185-S, which had been calibrated using the Czech Metrology Institute standards. Live measuring time ranged from 80550 to $91280 \mathrm{~s}$.

Spectral analysis was based on peaks at the

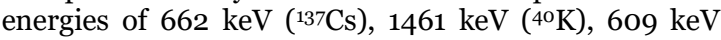
(214Bi) and $911 \mathrm{keV}\left({ }^{228} \mathrm{Ac}\right)$.

In order to estimate annual intake of radionuclides by an adult due to fish consumption, committed effective dose is calculated using

$\mathrm{E}=\mathrm{A}_{\mathrm{c}}\left({ }^{137 \mathrm{Cs}}\right) \cdot \mathrm{DC}\left({ }^{137} \mathrm{Cs}\right)+\mathrm{A}_{\mathrm{c}}\left({ }^{40} \mathrm{~K}\right) \cdot \mathrm{DC}\left({ }^{40} \mathrm{~K}\right)+\mathrm{A}_{\mathrm{c}}\left({ }^{214} \mathrm{Bi}\right)$

$\mathrm{DC}\left({ }^{214} \mathrm{Bi}\right)+\mathrm{A}_{\mathrm{c}}\left({ }^{228} \mathrm{Ac}\right) \cdot \mathrm{DC}\left({ }^{228} \mathrm{Ac}\right)$,

where $\mathrm{A}_{\mathrm{c}}$ is radionuclide activity concentration in eatable portion of fish (in $\mathrm{Bq} / \mathrm{kg}$ ), and $\mathrm{DC}$ is corresponding dose coefficient given by the International Commission on Radiological Protection (ICRP) in the publication 119 [16]: $1.3 \cdot 10^{-8}, 6.2 \cdot 10^{-9}$,

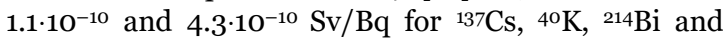
${ }^{228} \mathrm{Ac}$, respectively. The annual dose is calculated assuming an intake of $13 \mathrm{~kg}$ of fish meat - as typical for Europe.

\section{RESULTS}

The results of the fish muscle measurements are given in Table 1 (radionuclide activity concentrations) and Table 2 (element concentrations).

The samples of fish muscles for radioactivity measurements (Table 1) had a wet weight of 23, 38.3, $41.55,48.1$, 33.2 and $24.3 \mathrm{~g}$, respectively. Sign "<" means below minimum detectable activity (MDA) calculated using the $3 \mathrm{MDA}$ method, while " $\leq$ " - on a level of MDA, taking into account measuring errors.

In regards to results in Table 2, measuring uncertainty for seawater sample was $10 \%(\mathrm{Cu}, \mathrm{Fe}, \mathrm{Mn}$ and $\mathrm{Zn}$ ), for the mullet muscles $5.18 \%(\mathrm{~Pb})$ to $9.85 \%$ $(\mathrm{Fe})$, and for the other fish muscles from $5 \%(\mathrm{Fe})$ to $9.2 \%(\mathrm{Cu})$.

The THQ (Fig. 1) due to human intake of $\mathrm{Pb}, \mathrm{Cd}$ and both of them (total, THQ-Pb+THQ-Cd) by consuming considered fish species, is calculated using Eq. (1).

Table 1. Radionuclide activity concentrations $(\mathrm{Bq} / \mathrm{kg})$ in fish muscles and seawater

\begin{tabular}{|c|c|c|c|c|}
\hline & ${ }^{\mathbf{2 1 4} \mathbf{B i}}$ & ${ }^{\mathbf{1 3 7}} \mathbf{C s}$ & ${ }^{\mathbf{2 2 8}^{\mathbf{A c}}}$ & ${ }^{\mathbf{4}} \mathbf{K}$ \\
\hline European hake & $\leq 4.13$ & $1.92 \pm 0.78$ & $\leq 7.05$ & $167 \pm 11$ \\
\hline $\begin{array}{c}\text { European } \\
\text { seabass - juv. }\end{array}$ & $2.73 \pm 0.41$ & $\leq 1.08$ & $\leq 4.19$ & $115 \pm 7$ \\
\hline $\begin{array}{c}\text { Gilt-head sea } \\
\text { bream }\end{array}$ & $\leq 2.07$ & $\leq 0.95$ & $\leq 4.10$ & $145 \pm 7$ \\
\hline $\begin{array}{c}\text { Golden grey } \\
\text { mullet }\end{array}$ & $2.1 \pm 0.2$ & $<1$ & $<4$ & $124 \pm 7$ \\
\hline Leaping mullet & $<2.6$ & $<1.5$ & $<5.9$ & $97.6 \pm 7.2$ \\
\hline $\begin{array}{c}\text { Thinlip grey } \\
\text { mullet }\end{array}$ & $<3.6$ & $<2$ & $\leq 7.3$ & $95.4 \pm 8.2$ \\
\hline $\begin{array}{c}\text { Seawater } \\
\text { (in Bq/L) }\end{array}$ & $0.017 \pm 0.002$ & $\leq 0.004$ & $\leq 0.02$ & $8.25 \pm 0.28$ \\
\hline
\end{tabular}

Committed (annual) effective dose, representing annual intake of radionuclides due to an adult fish consumption (Eq.(2)), is shown in Fig. 2.
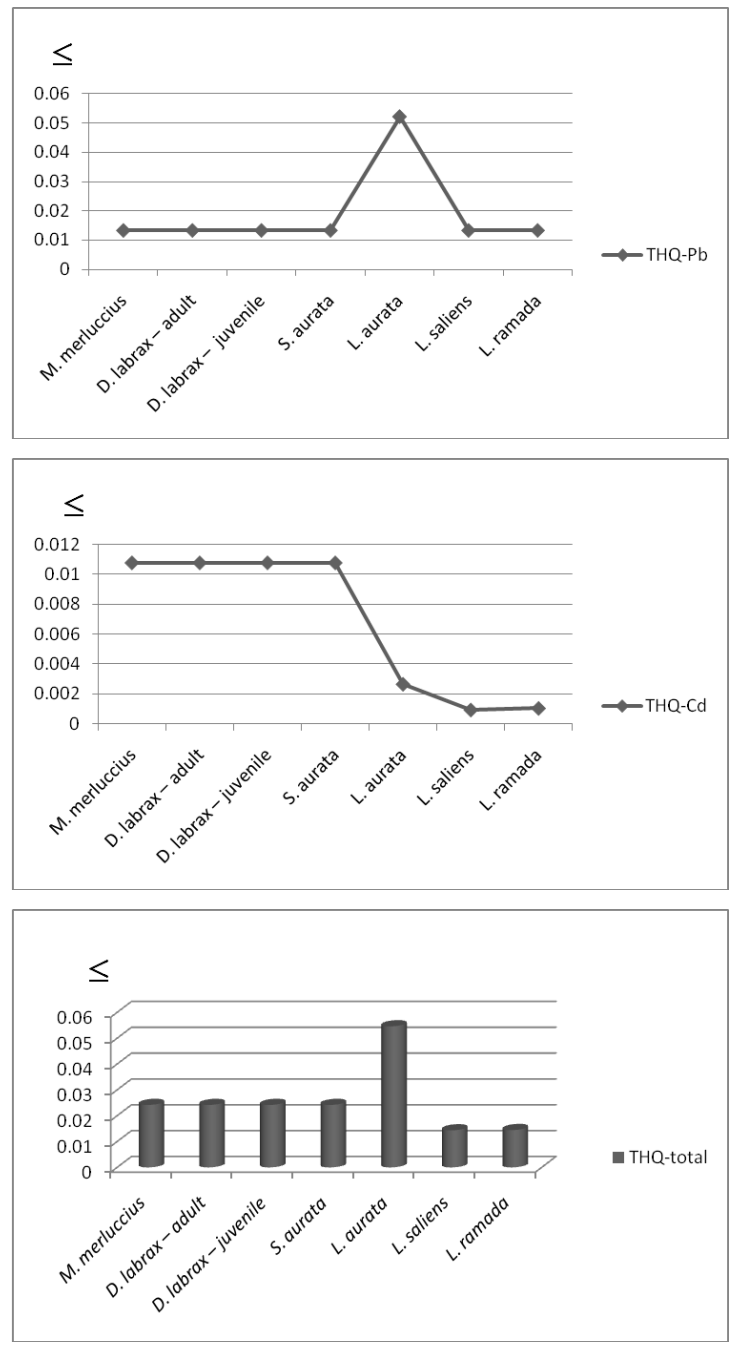

Figure 1. Target hazard quotients

Table 2. Element concentrations (in $\mathrm{mg} / \mathrm{kg}$ ) in fish muscles

\begin{tabular}{|c|c|c|c|c|c|}
\hline & $\mathrm{Pb}$ & $\mathrm{Cd}$ & $\mathrm{Cu}$ & $\mathrm{Fe}$ & $\mathrm{Mn}$ \\
\hline $\begin{array}{c}\text { European } \\
\text { hake }\end{array}$ & $<0.1$ & $<0.02$ & 0.16 & 1.7 & 0.09 \\
\hline $\begin{array}{c}\text { European } \\
\text { seabass } \\
\text { adult }\end{array}$ & $<0.1$ & $<0.02$ & 0.43 & 3.4 & 0.12 \\
\hline $\begin{array}{c}\text { European } \\
\text { seabass }- \\
\text { juvenile }\end{array}$ & $<0.1$ & $<0.02$ & 0.22 & 1.8 & 0.16 \\
\hline $\begin{array}{c}\text { Gilt-head } \\
\text { sea bream }\end{array}$ & $<0.1$ & $<0.02$ & 0.17 & 1.4 & 0.15 \\
\hline $\begin{array}{c}\text { Golden } \\
\text { grey } \\
\text { mullet }\end{array}$ & 0.387 & 0.0049 & 0.82 & 269 & 4.09 \\
\hline $\begin{array}{c}\text { Leaping } \\
\text { mullet }\end{array}$ & $<0.1$ & 0.0017 & 0.45 & 18.53 & 0.22 \\
\hline $\begin{array}{c}\text { Thinlip } \\
\text { grey } \\
\text { mullet }\end{array}$ & $<0.1$ & 0.0019 & 0.22 & 11.63 & 0.143 \\
\hline $\begin{array}{c}\text { Seawater } \\
\text { (mg/L) }\end{array}$ & $\leq 0.005^{*}$ & $\leq 0.0005$ & 0.002 & 0.03 & 0.007 \\
\hline
\end{tabular}

${ }^{*}$ Level of Detection 
I. Antović et al., Heavy metals and radionuclides..., RAP Conf. Proc., vol. 4, 2019, 96-102

Table 2. Cont.

\begin{tabular}{|c|c|c|c|}
\hline & $\mathrm{Ni}$ & $\mathrm{Cr}$ & $\mathrm{Zn}$ \\
\hline $\begin{array}{c}\text { European } \\
\text { hake }\end{array}$ & $<0.05$ & 0.10 & 3.3 \\
\hline $\begin{array}{c}\text { European } \\
\text { seabass - } \\
\text { adult }\end{array}$ & $<0.05$ & 0.02 & 3.9 \\
\hline $\begin{array}{c}\text { European } \\
\text { seabass - } \\
\text { juvenile }\end{array}$ & $<0.05$ & 0.08 & 4.4 \\
\hline $\begin{array}{c}\text { Gilt-head sea } \\
\text { bream }\end{array}$ & $<0.05$ & 0.07 & 4.0 \\
\hline $\begin{array}{c}\text { Golden grey } \\
\text { mullet }\end{array}$ & 1.14 & 5.07 & 5.33 \\
\hline $\begin{array}{c}\text { Leaping } \\
\text { mullet }\end{array}$ & 0.053 & 0.22 & 5.08 \\
\hline $\begin{array}{c}\text { Thinlip grey } \\
\text { mullet }\end{array}$ & 0.028 & 0.196 & 4.62 \\
\hline $\begin{array}{c}\text { Seawater } \\
\text { (mg/L) }\end{array}$ & $\leq 0.001^{*}$ & $\leq 0.001^{*}$ & 0.003 \\
\hline * Level of Detection & & & \\
\hline
\end{tabular}

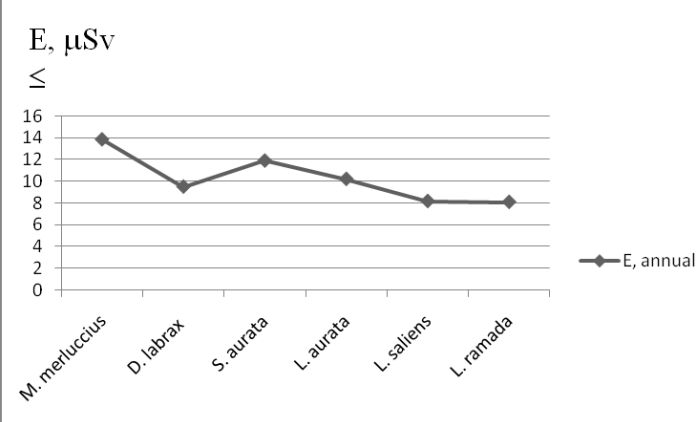

Figure 2. Effective dose due to ingestion of radionuclides in fish species

\section{DISCUSSION}

\subsection{Element concentrations}

In literature there are publications that report metal concentrations in various fish species and their organs [17-27]. The data reported in the literature in comparison with data of the present study are given in Tables 3 and 4 .

In regards to the Liza, L. aurata from the southern Atlantic coast of Spain [17], and the Caspian Sea [18], L. ramada from Lake Manzala, Egypt [19], L. saliens from the Esmoriz-Paramos coastal lagoon, Portugal [20] were investigated, as well as the other Liza species, but there were no data available about the Liza species from the South Adriatic, Coast of Montenegro.

Looking at the results reported in Table 2, in $L$. aurata muscle concentrations were ordered as: $\mathrm{Fe}>\mathrm{Zn}>\mathrm{Cr}>\mathrm{Mn}>\mathrm{Ni}>\mathrm{Cu}>\mathrm{Pb}>\mathrm{Cd}$, and it showed concentration of each element higher than the other two Liza (in particular, $\mathrm{Pb}, \mathrm{Fe}, \mathrm{Mn}, \mathrm{Ni}$, and $\mathrm{Cr}$ ). The concentration of only $\mathrm{Zn}$ could be considered as comparable in all the Liza muscles.

Moreover, transfer factor, i.e., the ratio of the $\mathrm{Pb}$, $\mathrm{Cd}, \mathrm{Cu}, \mathrm{Fe}, \mathrm{Mn}, \mathrm{Ni}, \mathrm{Cr}, \mathrm{Zn}$ concentrations in the Liza muscles and seawater, was found to be around 77 , $\geq 9.8,410,8967,584, \geq 1140, \geq 5070,1777$, respectively (L. aurata); 20, $\geq 3.8,110,388,20, \geq 28, \geq 196,1540$, respectively ( $L$. ramada); 20, $\geq 3.4,225,618,31, \geq 53$, $\geq 220,1693$, respectively (L. saliens).

Table 3. Element concentrations (in $\mathrm{mg} / \mathrm{kg}$ ) reported for muscles of the same fish species

\begin{tabular}{|c|c|c|c|c|c|}
\hline Species & $\mathrm{Pb}$ & $\mathrm{Cd}$ & $\mathrm{Cu}$ & $\mathrm{Fe}$ & Ref. \\
\hline L. aurata & $\begin{array}{c}\text { (0.03- } \\
0.05) \\
1.5 \\
0.387\end{array}$ & $\begin{array}{c}\left(0.013^{-}\right. \\
0.03) \\
0.35 \\
0.0049\end{array}$ & $\begin{array}{l}(0.2- \\
0.6) \\
4.54 \\
0.82\end{array}$ & $\begin{array}{c}(4.11- \\
7.13) \\
67.52 \\
269 \\
\end{array}$ & $\begin{array}{c}{[17]} \\
{[18]^{*}} \\
* *\end{array}$ \\
\hline L. ramada & $\begin{array}{c}\left(1.43^{-}\right. \\
2.43) \\
<0.1\end{array}$ & $\begin{array}{c}\left(0.51^{-}\right. \\
1.11) \\
0.0019\end{array}$ & $\begin{array}{c}\left(3.03^{-}\right. \\
4.66) \\
0.22\end{array}$ & $\begin{array}{c}- \\
11.63\end{array}$ & $\begin{array}{c}{[19]^{*}} \\
* *\end{array}$ \\
\hline L. saliens & $\begin{array}{c}- \\
<0.1 \\
\end{array}$ & $\begin{array}{c}- \\
0.0017\end{array}$ & $\begin{array}{c}<2.64 \\
0.45\end{array}$ & $\begin{array}{c}- \\
18.53 \\
\end{array}$ & $\begin{array}{c}{[20]^{*}} \\
* * \\
\end{array}$ \\
\hline D. labrax & $\begin{array}{l}1.58 \\
<0.1\end{array}$ & $\begin{array}{c}0.03 \\
<0.02\end{array}$ & $\begin{array}{l}0.33 \\
0.43\end{array}$ & $\begin{array}{c}11.13 \\
3.4\end{array}$ & {$\left[\begin{array}{c}{[21]^{*}} \\
* *\end{array}\right.$} \\
\hline S. aurata & $\begin{array}{l}1.11 \\
<0.1\end{array}$ & $\begin{array}{c}0.12 \\
<0.02\end{array}$ & $\begin{array}{l}0.55 \\
0.17\end{array}$ & $\begin{array}{c}11.12 \\
1.4\end{array}$ & $\begin{array}{c}{[21]^{*}} \\
* *\end{array}$ \\
\hline M. merlucc. & $\begin{array}{c}- \\
0.001 \\
<0.1\end{array}$ & $\begin{array}{c}- \\
- \\
<0.02\end{array}$ & $\begin{array}{c}0.258 \\
0.077 \\
0.16\end{array}$ & $\begin{array}{c}2.584 \\
0.307 \\
1.7\end{array}$ & $\begin{array}{c}{[22]} \\
{[23]} \\
* * *\end{array}$ \\
\hline Species & $\mathrm{Mn}$ & $\mathrm{Ni}$ & $\mathrm{Cr}$ & $\mathrm{Zn}$ & Ref. \\
\hline L. aurata & $\begin{array}{c}\left(2.25^{-}\right. \\
2.5) \\
- \\
4.09\end{array}$ & $\begin{array}{c}\text { (0.021- } \\
0.07) \\
0.73 \\
1.14\end{array}$ & $\begin{array}{c}\text { (0.029- } \\
0.038) \\
0.74 \\
5.07\end{array}$ & $\begin{array}{c}3.1- \\
8.41) \\
13.69 \\
5.33 \\
\end{array}$ & $\begin{array}{c}{[17]} \\
{[18]^{*}} \\
* *\end{array}$ \\
\hline L. ramada & $\begin{array}{c}- \\
0.143\end{array}$ & $\begin{array}{c}- \\
0.028\end{array}$ & $\begin{array}{c}- \\
0.196\end{array}$ & $\begin{array}{c}(12.6- \\
36.9) \\
4.62\end{array}$ & $\begin{array}{c}{[19]^{*}} \\
* *\end{array}$ \\
\hline L. saliens & $\begin{array}{c}- \\
0.22\end{array}$ & $\begin{array}{c}- \\
0.053\end{array}$ & $\begin{array}{c}- \\
0.22\end{array}$ & $\begin{array}{c}26 \\
5.08\end{array}$ & {$[20]^{* *}$} \\
\hline D. labrax & $\begin{array}{c}- \\
0.12\end{array}$ & $\begin{array}{c}- \\
<0.05\end{array}$ & $\begin{array}{c}- \\
0.02 \\
\end{array}$ & $\begin{array}{c}75.38 \\
3.9 \\
\end{array}$ & {$[21]^{*}$} \\
\hline S. aurata & $\begin{array}{c}- \\
0.15\end{array}$ & $\begin{array}{c}- \\
<0.05\end{array}$ & $\begin{array}{c}- \\
0.07\end{array}$ & $\begin{array}{c}76.98 \\
4.0\end{array}$ & {$[21]^{*}$} \\
\hline M. merlucc. & $\begin{array}{c}- \\
- \\
0.09\end{array}$ & $\begin{array}{c}- \\
- \\
<0.05\end{array}$ & $\begin{array}{c}- \\
- \\
0.10\end{array}$ & $\begin{array}{c}3.692 \\
1.27 \\
3.3\end{array}$ & $\begin{array}{l}{[22]} \\
{[23]} \\
* * *\end{array}$ \\
\hline
\end{tabular}

${ }^{*}$ Results reported for dry weight fish muscles

** Present study

Table 4. Element concentrations (in $\mathrm{mg} / \mathrm{kg}$ ) reported for muscles of some other fish species

\begin{tabular}{|c|c|c|c|c|c|}
\hline Species & $\mathrm{Pb}$ & $\mathrm{Cd}$ & $\mathrm{Cu}$ & $\mathrm{Fe}$ & Ref. \\
\hline Liza abu & - & - & 1.36 & 6.88 & [24] \\
\hline$M$ cenhalus & 1.19 & 0.08 & 0.62 & 11.12 & {$[21]^{*}$} \\
\hline м. серпатыs & 0.2 & 0.007 & 1.2 & 4.0 & [1] \\
\hline $\begin{array}{c}\text { Silurus } \\
\text { triostegus }\end{array}$ & - & - & 4.27 & 6.38 & [24] \\
\hline $\begin{array}{l}\text { Lepomis } \\
\text { gibbosus }\end{array}$ & 0.631 & 0.008 & 0.49 & 125 & [25] \\
\hline $\begin{array}{c}\text { Arius } \\
\text { thalassinus }\end{array}$ & $\begin{array}{l}- \\
-\end{array}$ & $\begin{array}{l}0.027 \\
0.058 \\
\end{array}$ & $\begin{array}{l}1.56 \\
1.21 \\
\end{array}$ & - & {$[26]^{*}$} \\
\hline $\begin{array}{l}\text { Johnius } \\
\text { belangeri }\end{array}$ & - & $\begin{array}{c}0.04 \\
0.055\end{array}$ & $\begin{array}{l}0.95 \\
0.66\end{array}$ & - & {$[26]^{*}$} \\
\hline Species & $\mathrm{Mn}$ & $\mathrm{Ni}$ & $\mathrm{Cr}$ & $\mathrm{Zn}$ & Ref. \\
\hline Liza abu & 0.40 & - & - & 7.74 & [24] \\
\hline M. cephalus & $\begin{array}{c}- \\
1.0\end{array}$ & $\begin{array}{l}- \\
-\end{array}$ & - & $\begin{array}{c}60.86 \\
3.9\end{array}$ & $\begin{array}{c}{[21]^{*}} \\
{[1]}\end{array}$ \\
\hline $\begin{array}{c}\text { Silurus } \\
\text { triostegus }\end{array}$ & 0.35 & 0.56 & - & 10.94 & [24] \\
\hline $\begin{array}{l}\text { Lepomis } \\
\text { gibbosus }\end{array}$ & 1.07 & - & - & 6.54 & [25] \\
\hline $\begin{array}{c}\text { Arius } \\
\text { thalassinus }\end{array}$ & $\begin{array}{l}0.92 \\
0.62\end{array}$ & $\begin{array}{l}- \\
-\end{array}$ & $\begin{array}{l}- \\
-\end{array}$ & $\begin{array}{l}30.21 \\
20.54 \\
\end{array}$ & {$[26]^{*}$} \\
\hline $\begin{array}{l}\text { Johnius } \\
\text { belangeri }\end{array}$ & $\begin{array}{l}0.97 \\
0.54\end{array}$ & $\begin{array}{l}- \\
-\end{array}$ & $\begin{array}{l}- \\
-\end{array}$ & $\begin{array}{l}13.12 \\
18.27\end{array}$ & {$[26]^{*}$} \\
\hline
\end{tabular}

${ }^{*}$ Results reported for dry weight fish muscles 
In $M$. merluccius muscle concentrations were ordered as: $\mathrm{Zn}>\mathrm{Fe}>\mathrm{Cu}>\mathrm{Cr}>\mathrm{Mn}>\mathrm{Pb}>\mathrm{Ni}>\mathrm{Cd}$, in $D$. labrax adult: $\mathrm{Zn}>\mathrm{Fe}>\mathrm{Cu}>\mathrm{Mn}>\mathrm{Pb}>\mathrm{Ni}>\mathrm{Cr}>\mathrm{Cd}$, in $D$. labrax juvenile: $\mathrm{Zn}>\mathrm{Fe}>\mathrm{Cu}>\mathrm{Mn}>\mathrm{Pb}>\mathrm{Cr}>\mathrm{Ni}>\mathrm{Cd}$, while in $S$. aurata: $\mathrm{Zn}>\mathrm{Fe}>\mathrm{Cu}>\mathrm{Mn}>\mathrm{Pb}>\mathrm{Cr}>\mathrm{Ni}>\mathrm{Cd}$.

A literature survey generally showed that among the mullet species, regarding the number of studies and number of the considered elements, $M$. cephalus and $L$. aurata were investigated more than the other mullets. Looking at Table $3, \mathrm{Fe}, \mathrm{Mn}, \mathrm{Ni}$ and $\mathrm{Cr}$ concentrations in the L. aurata muscles are higher than in the other species. The same species studied in [17] showed Mn concentration at least two times higher than the other species, while its Ni concentration was ten times lower than that reported in [18]. This confirms the previous findings, i.e., different species showed inter-specific variation in metal concentrations, and fish from the same species also showed significant variations. Additionally, the other researchers have already shown that seasonal variations of metal concentrations are significant, and liver or gills of various fish species accumulate metals in a higher amount than their muscles. Therefore, future research on the Liza from the South Adriatic should include particular element distribution (concentration) in different organs, as well as an evaluation of potential risk for the fish itself.

In particular, heavy metal concentrations revealed in the $L$. aurata muscle need further research. As mentioned above, a few heavy metals can be toxic even in trace amounts, while essential elements are not harmful to the organism except in high concentrations, which means that low intakes can result in nutritional deficiencies, while high intakes can result in toxicity.

Based on the here presented initial results and a survey of relevant literature, the comments and conclusions are as follows.

In regard to essential elements, $\mathrm{Fe}$ found in $L$. aurata muscle as eatable portion is generally higher than in the other species (comparable with that found in the liver of some species [2, 21]). In a literature survey given in [22], the other mullet species, $M$. cephalus, showed Fe concentrations of up to 129 $\mathrm{mg} / \mathrm{kg}$.

Related to the other essential trace elements, such as $\mathrm{Zn}$ and $\mathrm{Cu}$, in $M$. merluccius muscle from the central Adriatic, Italy, as reported in [27], their concentrations (around 22.9 and $5.7 \mathrm{mg} / \mathrm{kg}$, respectively) were found to be several times higher than those measured in $M$. merluccius from the South Adriatic, Montenegro (3.3 and $0.16 \mathrm{mg} / \mathrm{kg}$ ). In $M$. merluccius from the Northeastern Mediterranean Sea [22] $\mathrm{Zn}, \mathrm{Cu}$, and $\mathrm{Fe}$ concentrations are found to be similar to those in $M$. merluccius from the South Adriatic. In the case of $L$. aurata from the South Adriatic $\mathrm{Zn}$ and $\mathrm{Cu}$ concentrations are found to be comparable with those in the same species from Spain (as given in [17]).

On the other hand, Mn concentration of 4.09 $\mathrm{mg} / \mathrm{kg}$ in L. aurata is significantly higher than in the other fish species (Tables 3 and 4 ). The same can be said for L. aurata from the southern Atlantic coast of Spain (see [17], i.e. Table 3). As can be seen from Table 2 , its concentration in the South Adriatic seawater was found to be $0.007 \mathrm{mg} / \mathrm{L}$, while in one beach sand sample from the Coast of Montenegro, it had been 597 $\mathrm{mg} / \mathrm{kg}$, and $\mathrm{Cr}-78.7 \mathrm{mg} / \mathrm{kg}$ [9]. Although $\mathrm{Cr}$ in seawater was at the level of detection, in L. aurata it is several times higher than that reported in $[17,18]$.

Considering previously mentioned international regulations [3-6], only $\mathrm{Cr}$ in L. aurata exceeded the permissible limit. Furthermore, looking at toxic trace elements, i.e. $\mathrm{Pb}$ and $\mathrm{Cd}$ concentrations, muscle of $L$. aurata showed $\mathrm{Pb}$ slightly above $0.3 \mathrm{mg} / \mathrm{kg}$ - a limit given in the Montenegro regulations [8].

Comparing THQs data for the analyzed fish species (Fig. 1) with the other ones, for example Thunnus alalunga (Bonnaterre, 1788) from the Aegean Sea, Greece [15], it can be concluded that THQ-Pb for $L$. aurata is significantly higher (around 0.052, in comparison to the maximum of 0.0075 for $T$. alalunga), while THQ-Cd is lower (a mean THQ-Cd for T. alalunga from two areas of the Aegean Sea is found to be 0.099 and 0.044 [15]).

\subsection{Radionuclide activity concentrations}

Activity concentrations of radioactive isotopes in fish muscles given in Table 1 show a level of ${ }^{137} \mathrm{Cs}$ somewhat lower than in the muscles of the other mullet species from the South Adriatic Sea, such as $C$. labrosus $(2.8 \mathrm{~Bq} / \mathrm{kg}$ in average, as reported in 2011 [13]), the species in which ${ }^{226} \mathrm{Ra}$ in muscles ranged from 0.88 to $1.95 \mathrm{~Bq} / \mathrm{kg}$, with an average of $1.5 \mathrm{~Bq} / \mathrm{kg}$ [13]. The ${ }^{214} \mathrm{Bi}$ activity of the presently-analyzed muscles seems to be somewhat higher. At the same time, another mullet species from the South Adriatic Sea, $M$. cephalus, analyzed previously for a level of ${ }^{232} \mathrm{Th}$ [12], showed maximum activity concentrations in muscles of $1.57 \mathrm{~Bq} / \mathrm{kg}$ [12].

Fish consumption by an adult brings intake of radionuclides at an annual level characterized by the committed effective dose shown in Fig. 2. The highest one (around $13.8 \mu \mathrm{Sv}$ ) was found for the muscle of $M$. merluccius extensively consumed by the local and wider Montenegro population. It is important to note that activity concentrations of all the radionuclides, in this case, were equal or above the minimum detectable activity (see Table 1), as well as in the case of D. labrax juvenile showing a corresponding effective dose of around $9.5 \mu \mathrm{Sv}$ annually. A worldwide average committed effective doses (to adults) due to the ingestion of Ra-226 and Th-232 were estimated to be 6.3 and $0.38 \mu \mathrm{Sv}$, respectively [28].

\section{CONCLUSION}

The muscles of six fish species from the South Adriatic Sea adjacent to Montenegro have been analyzed on metals ( $\mathrm{Pb}, \mathrm{Cd}, \mathrm{Cu}, \mathrm{Fe}, \mathrm{Mn}, \mathrm{Ni}, \mathrm{Cr}, \mathrm{Zn})$, and radionuclides $\left({ }^{137} \mathrm{Cs},{ }^{40} \mathrm{~K},{ }^{214} \mathrm{Bi},{ }^{228} \mathrm{Ac}\right)$. The main results can be summarized as:

- Fe concentration found in L. aurata is generally higher than in muscles of some other fish species,

- Mn concentration found in L. aurata is significantly higher than in muscles of some other fish species,

- $\quad$ Cr concentration found in L. aurata exceeds 1 $\mathrm{mg} / \mathrm{kg}$, 
- Pb concentration found in L. aurata is slightly above a limit given in the Montenegro regulations,

- committed effective dose due to intake of radionuclides by fish consumption, was found to be the highest for the muscle of $M$. merluccius.

All the results presented here indicate that the marine environment of the South Adriatic should be further investigated - ecotoxicologically and radioecologically, applying an integrated approach.

Acknowledgements: The paper is a part of the research done within the project supported by the Ministry of Science of Montenegro (01-571).

\section{REFERENCES}

1. R. J. Medeiros et al., "Determination of inorganic trace elements in edible marine fish from Rio de Janeiro State, Brazil," Food Control, vol. 23, no. 2, pp. 535 541, Feb. 2012.

DOI: 10.1016/j.foodcont.2011.08.027

2. K. M. El-Moselhy, A. I. Othman, H. A. El-Azem, M. E. A. El-Metwally, "Bioaccumulation of heavy metals in some tissues of fish in the Red Sea, Egypt," Egypt. J. Basic and Appl. Sci., vol. 1, no. 2, pp. 97 - 105, Dec. 2014.

DOI: 10.1016/j.ejbas.2014.06.001

3. Evaluation of certain food additives and the contaminants mercury, lead, and cadmium, WHO Technical Report Series No. 505, WHO, Geneva, Switzerland, 1972.

Retrieved from:

https://apps.who.int/iris/bitstream/handle/10665/409 85/WHO TRS 505.pdf

Retrieved on: Feb. 07, 2016

4. Compilation of legal limits for hazardous substances in fish and fishery products, FAO Fisheries Circular No. 764, FAO, Rome, Italy, 1983.

Retrieved from:

http://www.fao.org/3/q5114e/q5114e.pdf

Retrieved on: Jan. 26, 2017

5. Evaluation of certain food additives and the contaminants, WHO Technical Report Series No. 776, WHO, Geneva, Switzerland, 1989.

Retrieved from:

https://apps.who.int/iris/bitstream/handle/10665/392 52/WHO TRS 776 .pdf

Retrieved on: Feb. 07, 2016

6. The Commission of European Communities. (Jan. 19, 2005). COMMISSION REGULATION (EC) No. 78/2005. Amending Regulation (EC) No. 466/2001 as regards heavy metals.

Retrieved from:

https://eur-

lex.europa.eu/LexUriServ/LexUriServ.do?uri=OJ:L:20 05:016:0043:0045:EN:PDF

Retrieved on: Nov. 15, 2015

7. Savezna vlada Savezne Republike Jugoslavije. (Maj 28, 1992). Br. 05/92. Pravilnik o kolicinama pesticida, metala $i$ metaloida $i$ drugih otrounih supstancija, hemioterapeutika, anabolika i drugih supstancija koje se mogu nalaziti u namirnicama.

(Federal Government of the Federal Republic of Yugoslavia. (May 28, 1992). No. 05/92. Ordinance on the quantities of pesticides, metals and metalloids and other toxic substances, chemotherapeutics, anabolics and other substances which may be present in foods.) Retrieved from:

http://extwprlegs1.fao.org/docs/pdf/yug72666.pdf Retrieved on: Feb. 04, 2016
8. Službeni list Crne Gore. (Dec. 8, 2009, Sep. 30, 2015). br. 81/20o9, 55/2015. Pravilnik o dozvoljenim količinama teških metala, mikotoksina $i$ drugih supstanci u hrani.

(Official Gazette of Montenegro. (Dec. 8, 2009, Sep. 30, 2015). No. 81/2009, 55/2015. Rulebook on the allowable amounts of heavy metals, mycotoxins and other substances in food.)

Retrieved from:

http://www.mzdravlja.gov.me/ResourceManager/FileD ownload.aspx? rid $=236146 \&$ rType $=2 \&$ file $=$ Pravilnik $\% 2$ oo\%2odozvoljenim\%2okoli\%C4\%8Dinama\%20te\%C5 \%A1kih\%2ometala,\%2omikotoksina\%2oi\%2odrugih\%2 osupstanci\%20u\%2ohrani.pdf; Retrieved on: Apr. 24, 2016

9. N. M. Antovic, N. Svrkota, I. Antovic, R. Svrkota, D. Jančić, "Radioactivity in Montenegro beach sands and assessment of the corresponding environmental risk," Isot. Environ. Health Stud., vol. 49, no. 2, pp. $153-162$, Jun. 2013.

DOI: $10.1080 / 10256016.2013 .734303$

PMid: 23452289

10. J.M. Thomson, "The Mugilidae of the world," Mem. Qld. Mus., vol. 41, no. 3, pp. 457 - 562, 1997.

Retrieved from:

http://biostor.org/pdfproxy.php?url=https\%3A\%2F\%2

Farchive.org\%2Fdownload\%2Fbiostor-

105310\%2Fbiostor-105310.pdf

Retrieved on: Mar. 20, 2019

11. Species fact sheet, FAO, Rome, Italy.

Retrieved from:

http://www.fao.org/fishery/species/search/en

Retrieved on: Jun. 03, 2019

12. N. M. Antovic, I. Antovic, N. Svrkota, "Levels of ${ }^{232} \mathrm{Th}$ activity in the South Adriatic Sea marine environment of Montenegro," J. Radioanal. Nucl. Chem., vol. 284, no. 3, pp. 605-614, Jun. 2010. DOI: $10.1007 / \mathrm{s} 10967-010-0512-\mathrm{x}$

13. I. Antovic, N. M. Antovic, "Determination of concentration factors for Cs-137 and Ra-226 in the mullet species Chelon labrosus (Mugilidae) from the South Adriatic Sea," J. Environ. Radioact., vol. 102, no. 7, pp. 713-717, Jul. 2011.

DOI: 10.1016/j.jenvrad.2011.04.006

PMid: 21514703

14. I. Antovic, N. Svrkota, N. M. Antovic, "Beryllium-7 in six fish species from the Bay of Boka Kotorska," in Book of Abstr. 7th Int. Conf. Radiation in Various Fields of Research (RAD 2019), Herceg Novi, Montenegro, 2019, p. 437.

Retrieved from: http://www.radconference.org/books.php Retrieved on: May 15, 2019

15. N. Stamatis, N. Kamidis, P. Pigada, D. Stergiou, A. Kallianiotis, "Bioaccumulation levels and potential health risks of mercury, cadmium, and lead in Albacore (Thunnus alalunga, Bonnaterre, 1788) from the Aegean Sea, Greece," Int. J. Environ. Res. Public Health, vol. 16 , no. 5 , p. 821 , Mar. 2019.

DOI: $10.3390 /$ ijerph16050821

PMid: 30845745

PMCid: PMC6427763

16. Compendium of dose coefficients based on ICRP Publication 6o, vol. 41, ICRP Publication no. 119, ICRP, Ottawa, Canada, 2012.

Retrieved from:

http://www.icrp.org/docs/P\%20119\%20JAICRP\%2041 (s)\%20Compendium\%200f\%20Dose\%20Coefficients\% 2obased\%200n\%20ICRP\%20Publication\%2060.pdf Retrieved on: Mar. 30, 2016

17. J. Usero, C. Izquierdo, J. Morillo, I. Gracia, "Heavy metals in fish (Solea vulgaris, Anguilla anguilla and Liza aurata) from salt marshes on the southern Atlantic coast of Spain," Environ. Int., vol. 29, no. 7, pp. $949-956$, Jan. 2004. DOI: 10.1016/So160-4120(03)ooo61-8 
PMid: 14592572

18. H. T. Jelodar, M. S. Baei, S. H. Najafpour, H. Fazli, "The comparison of heavy metals concentrations in different organs of Liza aurata inhabiting in southern part of Caspian Sea," World Appl. Sci. J., vol. 14, spec. issue, pp. $96-100,2011$

Retrieved from:

https://www.academia.edu/31511122/The Comparison of Heavy Metals Concentrations in Different Org ans of Liza aurata Inhabiting in Southern Part of Caspian Sea

Retrieved on: Jan. 23, 2019

19. M. H. Bahnasawy, A. A. Khidr, N. Dheina, "Seasonal variations of heavy metals concentrations in mullet, Mugil cephalus and Liza ramada (Mugilidae) from Lake Manzala, Egypt," Egypt. J. Aquat. Biol. Fish., vol. 13, no.2, pp. 81 - 100, Apr. 2009.

DOI: $10.21608 /$ ejabf.2009.2034

20. C. Fernandes, A. Fontaínhas-Fernandes, F. Peixoto, M. A. Salgado, "Bioaccumulation of heavy metals in Liza saliens from the Esmoriz-Paramos coastal lagoon, Portugal," Ecotoxicol. Environ. Saf., vol. 66, no. 3, pp. 426 - 431, Mar. 2007.

DOI: 10.1016/j.ecoenv.2006.02.007

PMid: 16620977

21. M. Dural, M. Z. L. Goksu, A. A. Ozak, "Investigation of heavy metal levels in economically important fish species captured from the Tuzla lagoon," Food Chem., vol. 102, no. 1, pp. $415-421$, Dec. 2007

DOI: 10.1016/j.foodchem.2006.03.001

22. M. P. Olgunoglu, E. Artar, İ. A. Olgunoglu, "Comparison of heavy metal levels in muscle and gills of four benthic fish species from the Northeastern Mediterranean Sea," Pol. J. Environ. Stud., vol. 24, no. 4, pp. $1743-1748,2015$. DOI: $10.15244 /$ pjoes $/ 38972$

23. A. Ozyilmaz, A. Demirci, D. B. Konuskan, S. Demirci, "Macro minerals, micro minerals, heavy metal, fat, and fatty acid profiles of European hake (Merluccius merluccius Linnaeus, 1758) caught by gillnet," $J$. Entomol.Zool. Stud., vol. 5, no. 6, pp. 272 - 275, 2017. Retrieved from:

http://www.entomoljournal.com/archives/2017/vol5iss ue6/PartD/5-5-219-283.pdf

Retrieved on: Jun. 04, 2019

24. H. Karadede, S. A. Oymak, E. Unlu, "Heavy metals in mullet, Liza abu, and catfish, Silurus triostegus, from the Ataturk Dam Lake (Euphrates), Turkey," Environ. Int., vol. 30, no. 2, pp. 183 - 188, Apr. 2004.

DOI: $10.1016 /$ So160-4120(03)00169-7

PMid: 14749107

25. F. Yılmaz, N. Özdemir, A. Demirak, A. L. Tuna, "Heavy metal levels in two fish species Leuciscus cephalus and Lepomis gibbosus," Food Chem., vol. 100, no. 2, pp. $830-835,2007$.

DOI: 10.1016/j.foodchem.2005.09.020

26. F. H. Bashir, M. S. Othman, A. G. Mazlan, S. M. Rahim, K. D. Simon, "Heavy metal concentration in fishes from the coastal waters of Kapar and Mersing, Malaysia," Turk. J. Fish. Aquat. Sci., vol. 13, no. 2, pp. $375-382$, Jun. 2013. Retrieved from: https://pdfs.semanticscholar.org/6ddd/3fb720468196 62c96a07964ccd8eoed5d9bf.pdf Retrieved on: May 17, 2019

27. M. Perugini et al., "Heavy metal (As, $\mathrm{Cd}, \mathrm{Hg}, \mathrm{Pb}, \mathrm{Cu}, \mathrm{Zn}$, Se) concentrations in muscle and bone of four commercial fish caught in the central Adriatic Sea, Italy," Environ. Monit. Assess., vol. 186, no. 4, pp. 2205 - 2213, Apr. 2014.

DOI: $10.1007 /$ s10661-013-3530-7

PMid: 24242233

28. Sources and Effects of Ionizing Radiation, Annex B, Rep. A/55/46, UNSCEAR, New York (NY), USA, 2000. Retrieved from:

https://www.unscear.org/docs/publications/2000/UN SCEAR 2000 Annex-B.pdf

Retrieved on: Jun. 25, 2016 